\title{
Analysis Implementation Al-Islam and Kemuhammadiyahan (AIK) Values in University Subjects (Case Study: Industrial Engineering Study Program FT-UMJ)
}

\author{
Mutmainah, Didi Sunardi, Annisa Mulia Rani \\ Department of Industrial Engineering, Universitas Muhammadiyah Jakarta, Indonesia
}

\begin{abstract}
Internalization of AIK is also a Quality Target and Quality Standard of the Learning Process at the Faculty of Engineering, University of Muhammadiyah Jakarta (FT-UMJ.) The objectives of this research are 1) to map the implementation of the Internalization of AIK implementation in the subjects taught at the IT-FTUMJ Study Program, 2) to identify problems and obstacles experienced in carrying out the internalization of AIK values in courses, 3) Recommending proposed strategies in their implementation.
\end{abstract}

The research method is a descriptive, qualitative method, with a case study. Data collection techniques are documents and interviews. The informants in this study were 11 (eleven) permanent lecturers at the Faculty of Engineering who taught 46 core courses. The documents seen are the IT Study Program Vision, Semester Learning Plans (RPS), Teaching Assignments and Quality Goals.

The results showed that only 4 courses included AIK material in the RPS or $8.6 \%$ of 46 courses. The results of the interview show that not all lecturers understand the Internalization of AIK, which has been given so far to the extent of Islamic values regarding behavior. Rules / Decree of the Chancellor regarding the Internalization of AIK, have never seen but have heard of an appeal or order from the leadership, Internalization of AIK in courses is very important to be included in the RPS so that it becomes the difference between RPS at UMJ and other universities and as an indicator of the achievement of the vision of the IT study program in Islamic aspect. The obstacles experienced by lecturers are due to the limited religious knowledge possessed by lecturers to examine AIK values related to courses. Recommendations in this study are to encourage leaders to issue policies or rules regarding the obligation to carry out AIK Internalization in courses listed in the RPS, make written guidelines and rules regarding technical implementation, conduct socialization to lecturers, provide assistance and guidance to lecturers, conduct monitoring \& evaluation and Follow-up Improvements, so that it is a continuous process (continuous improvement).

Keyword - Internalization of Values, AIK, RPS, qualitative descriptive, Quality Standards.

\section{INTRODUCTION}

$\mathrm{M}$ uhammadiyah Higher Education is a form of Muhammadiyah Charity Business for the Republic of
Indonesia and as the participation of Muhammadiyah in advancing education and people's lives. Universities have a big role in instilling the values of life in students. Values education is not just a special program taught through courses, but includes the entire educational process. The targets of his da'wah are students through AIK learning which is one of the characteristics of Muhammadiyah \& Aisyiyah Higher Education (PTMA). The achievement of Muhammadiyah da'wah at PTMA is not only a burden for AIK, but also needs to be supported by non-AIK courses that internalize Islamic values in their learning activities. This is one of the efforts to make Muhammadiyah's da'wah at PTMA a success [1].

Al-Islam and Kemuhammadiyahan (AIK) is a wisdom that should be achieved in every educational organization within Muhammadiyah for the formation of human learners who are pious, have noble character, progress and excel in science and technology as the embodiment of tajdid da'wah amar ma'ruf nahi munkar. Al-Islam Kemuhammadiyahan (AIK) is one of the compulsory subjects which is an integral part of the curriculum given in every Muhammadiyah educational institution, with the hope of influencing the character of students both during the education process, especially after they graduate [2]. Thus, the target to be achieved is to make Muhammadiyah education graduates who have the right faith, noble character, intelligent, skilled and ready to serve the interests of Islam and society can be realized.

Internalization is an effort to appreciate and explore values, so that they are embedded in every human being. The stages of value internalization in character or moral education include several things, namely Value Transformation, Value Transactions and Transinternalization [3] .

AIK values can be integrated in academic and nonacademic activities. Integrated in academic activities include integrated AIK values in learning activities for non-AIK subjects and one of the goals is to produce graduates who have pedagogic, professional, personality and social competencies[4]. Based on this goal, one of the people who are responsible for realizing that goal is the lecturer. 
Industrial Engineering Study Program, Faculty of Engineering, University of Muhammadiyah (TI-FTUMJ), was established in 1974 and obtained B Accreditation. Currently, TI-FTUMJ has 12 permanent lecturers. One of the realizations of the Islamic vision is the Internalization of AIK Values in courses, which are contained in the Semester Learning Plan (RPS). In each course, $75 \%$ of the lecturers have internalized AIK in their subject [10].

From preliminary observations by looking at the Industrial Engineering Curriculum document, it is known that the courses at TI-FTUMJ amount to 81 courses (including practicum, practical work and Final Project). Searching through the RPS document, there is no single course at TIFTUMJ that includes AIK subjects related to the courses being taught. It is necessary to identify problems and obstacles experienced by lecturers in internalizing AIK scores in courses and provide strategic solutions in implementing their implementation.

This research is considered very important for the realization of the Vision and Mission of the IT-FTUMJ study program in achieving the target of increasing the Accreditation Value of the Study Program as well as in achieving the Quality Goals and Quality Standards on the Standards of the Teaching Process of the Faculty of Engineering that have been declared.

\section{LITERATURE REVIEW}

\section{Definition of Internalization And Values}

Etymologically in the Indonesian Dictionary, the word internalization indicates a process, because in Indonesian terms, the suffix Isasi means process. The term internalization is expressed as a deep appreciation, namely appreciation of a teaching, doctrine, or value so that it is a belief and awareness of the truth of a doctrine or value that is manifested in attitudes and behavior carried out through guidance and so on [10].

The internalization is a process of people gaining beliefs, attitudes, values, and habits in their culture. Internalization is the process of an individual learning to interact with each other in a society according to the system of values, norms, and customs that govern the society concerned[3].

The process of internalization occurs in social institutions or groups in society. Community groups that play an important role in internalization are family, playmates, schools, work environment, and mass media [5]. According to Horton and Hunt that value is: "the idea of whether experience is meaningful or not"[6]. A person will take an action according to the experience he has experienced, regarding good experiences and bad experiences, depending on what value has been given through internalization in his family [7].

It is said by other figures such as Frankel, the discussion of values will be related to the dimensions of ideas/concepts and emotions.
Thus, understanding the value must be done in two ways, namely[8]:

1. Value is an idea about the usefulness or usefulness of something. In other words, values are concepts or abstractions

2. Value is something that is emotional, as something that is emotional, then value is a strong emotional commitment or a strong desire for something. Values are not only understanding, but have the impetus to realize that understanding. Value is the direction of a person's behavior.

3. Value is an understanding of something, but in that sense it contains the potential to encourage someone to make it happen in reality. Values are both cognitive and affective. Cognitive because value is an idea or concept. Meanwhile, value is also affective because it is a feeling that can be enjoyed and has the impetus to be realized immediately.

\section{Al-Islam and Kemuhammadiyahan}

Muhammadiyah education is a modern Islamic education that integrates religion with life and between faith and holistic progress. Progressive Islamic education. Science and Technology is the result of holistic and comprehensive rational thinking on the reality of the universe (verse kauniyah) and on revelation and sunnah (verse qauliyah) which are one unit. Mastery of science and technology is the first step in growing awareness of makrifat (faith/tawhid), so rational thinking is the beginning of spiritual awareness of divine wisdom. The service of worship to Allah includes worship that is summarized in the pillars of Islam, research and development of science and technology, sustainable environmental management in a civilized, just, and prosperous common life, as well as the liberation of everyone from suffering due to ignorance and poverty [9]. The vision of Muhammadiyah Education as stated in the 46th Muhammadiyah Conference Decision on Revitalizing Muhammadiyah Education: "The formation of human learners who are devoted, have noble character, progress and excel in science and technology as the embodiment of tajdid da'wah amar ma'ruf nahi munkar" [9]. The vision of the Muhammadiyah Higher Education (PTM) as formulated by PP Muhammadiyah's Majlis Dikti is "The establishment of good PTM governance towards sustainable quality improvement". This vision requires PTM to improve quality in various aspects including $\mathrm{Al}$ Islam and Kemuhammadiyahan (AIK) education. PTM has the mandate to realize one of Muhammadiyah's missions, namely to organize AIK education as part of the da'wah for good and evil[10].

\section{AikIntemalization in Courses}

Moral improvement for students is given in learning activities in both AIK courses and non AIK/general scientific subjects. The role of lecturers is very large in realizing the vision of education in PTM. Efforts are made by internalizing 
AIK values in courses. And learning activities. The internalization is an effort to appreciate and explore values, so that they are embedded in every human being. The stages of internalizing values in character or moral education include several things, namely as follows [11]:

1) Value transformation, namely the stage where the lecturer informs the good and bad values by using verbal communication;

2) Value transaction, which is a stage of character education by conducting two-way communication between lecturers and students accompanied by examples in everyday life;

3) Transinternalization, namely this stage which is further than just giving an example but already with the implementation of values. Shown by the expected mental attitude and personality.

The purpose of the internalization stage, namely the formation of morals in students. Moral improvement is one of the main goals in education. Morals that are implemented in life become one of the successes of the world of education. Learning activities are activities that are both physical and mental [9].

\section{III.RESEARCH METHODS}

This research was conducted for 4 months starting from the preparation of the proposal in April until the beginning of August 2021. The place of research is in the Industrial Engineering Study Program, Faculty of Engineering, University of Muhammadiyah Jakarta. This study uses a methodology with a qualitative approach, which has natural characteristics (natural setting) as a direct data source, descriptive, process is more important than results, analysis tends to be done inductively and meaning is essential, supported by case studies which is done to study intensively about the background of the current situation, and the environmental interactions of a social unit, namely: individuals, groups, institutions, or communities.

While the research procedure is as follows.

1. Determine the focus of qualitative research.

2. Determine the consideration of the type of qualitative research (case study) in accordance with the research focus.

3. Identification of cases, including individuals, a number of individuals, a program, an event, and an activity related to AIK

4. Carry out data collection including interviews and documents,

5. Data analysis, based on a holistic analysis of all cases. Detailed description of the case under study, case history, chronology of events, daily activities. Theme analysis, context analysis. Interpretation of the meaning of the case.

6. Reporting research results, research reports in detail the cases/cases studied in detail.
Data and Sources of Data Collected

a. Information about the introduction and understanding of lecturers on the internalization of AIK values in courses. Data sources from Permanent Lecturers of Industrial Engineering are 11 (eleven) people.

b. The data from the quality documents are the Quality Goals of the UMJ Faculty of Engineering and the UMJ Learning Process Standards. Source of data from the Quality Assurance Unit, Faculty of Engineering, UMJ.

c. Curriculum and Semester Learning Plans (RPS) for IT-FTUMJ courses. Another reference is related Journals and Books. Data Source from Industrial Engineering Study Program FTUMJ

To collect data, data collection techniques in research are adjusted to the focus and objectives of the study, which are as follows.

a. Documentation Studies.

Documentation studies are looking for data and information related to the AIK Implementation process in courses through the AIK Education Guidelines from the Muhammadiyah Central Executive Board of Higher Education, Rector's Decree on Islamic Campuses, Quality Standards for Learning Processes, Quality Goals, IT-FTUMJ Curriculum, RPS courses TI-FTUMJ and the Vision and Mission of TI-FTUMJ. Other references are appropriate Journals and Books.

b. Interview. Interviews were conducted on several sources at the research location, which aimed to obtain primary data from the informants. Interviews were conducted in accordance with the types of interviews, namely structured and unstructured interviews. In this study, the interview technique used by the researcher was in-depth interview, meaning that the researcher asked several questions in depth related to the focus of the problem. So that the data needed in the study can be collected maximally. Meanwhile, the number of informants taken consists of: 11 (eleven) Permanent Lecturers of the IT-FTUMJ Study Program. Interviews were conducted online. Every session for every lecturer

\section{RESULT}

\section{Discussion}

Understanding of AIK's Internalization

a. Not all lecturers understand about AIK Internalization Lecturers who understand only know but are still confused in its application

b. The understanding of AIK Internalization in courses has never been socialized on its implementation. So far, 
it is only an appeal and recommendation by the faculty leadership.

c. Internalization of AIK in courses has become one of the items in the FT Quality Goals and the quality standard of the learning process. It is stated in the PP Muhammadiyah Higher Education Council AIK educational guidelines,

There are things that must be considered, that the quality objectives and quality standards must be translated and implemented appropriately for lecturers and students. This is important, so that the quality objectives and quality standards that have been set can be achieved.

\section{Implementation of Internalization}

a. So far, lecturers carry out AIK Internalization in the learning process only regarding Islamic behavior, but even then they do not use the arguments of the Qur'an and/or Hadith, only advise on truth, honesty, motivation and examples of experience. Reading the basmalah, studying prayer, closing the assembly prayer, and hamdalah

b. There are several courses, especially social courses that include Internalization of AIK in the course material

c. In 2017, there was a cult regarding moral development using the Moral Development Guide book published by the Faculty. Implemented for 1 year, after that it is no longer done

According to the lecturer, the implementation of AIK Internalization is currently only at the stage of delivering AIK values in Islamic behavior.

The delivery of Islamic values is given to motivate students and change behavior.

Internalization is not only limited to giving Islamic values in behavior but also must be done by linking course material with related verses of the Qur'an and hadith. By linking this, the hope to produce Islamic graduates in accordance with the Institution's Vision will be achieved.

Giving Islamic values to behavior should be done by providing arguments that are in accordance with the Qur'an and Hadith

Lecturers have not carried out Internalization of AIK into course material, due to the limitations of Religious Studies. Therefore, it is necessary to provide guidance, assistance, tutorials by AIK Lecturers

\section{Application Results}

The results of implementing AIK values in the learning process with a focus on Islamic behavior, so far have not been in line with the expectations of the lecturers. Lecturers always give good values and motivation. This can be seen from their attitudes and motivations that have not changed.
Some lecturers give rewards and punishments to students who follow the rules of attendance and assignment discipline.

Giving AIK values for Islamic behavior carried out by lecturers, because of the awareness and instincts of lecturers as educators and not recommendations or orders from the leadership

Results The application of AIK values to behavior cannot be done quickly/instantly but requires a process. Therefore, the development of AIK values must also be carried out with a systematic, consistent, continuous improvement process with the commitment of the entire academic community.

The results of applying AIK values to behavior according to lecturers are still not as expected, this assessment is based on this based on the results in interactions with students both in lectures and daily.

However, the results of the implementation carried out at this time cannot be said to be unsuccessful, because research has not been carried out on the impact of giving AIK values in changing student behavior.

\section{Internalization Rules}

Rules/Rector's Decree regarding the Internalization of AIK, all lecturers have never seen but have heard an appeal or order from the leadership.There has never been an obligation to carry out AIK internalization but only an appeal, but the form of implementation has not been understood by the lecturers. Internalization of AIK values regarding Islamic behavior change is carried out because of the instincts / awareness of lecturers.

The Chancellor's Decree regarding Internalization has never been issued to lecturers. There are also no other regulations that require lecturers to internalize the value of AIK.

\section{AIK on courses and behavior.}

After searching the documents, it turns out that it has been implicitly stated in the PP Muhammadiyah Higher Education Council AIK educational guidelines, but at the University level there is no regulation/Rector's Decree that regulates the Internalization of AIK in courses. Internalization of AIK in courses is limited to an appeal or enthusiasm from the leadership to realize the Islamic vision. The internalization of AIK is also contained in the quality targets of the Faculty of Engineering and learning quality standards, but the technical guidelines, guidelines and implementation policies have not been regulated. Therefore, it is natural that lecturers have not carried out AIK Internalization in courses.

\section{The Importance of Internalizing AIK in Courses}

All lecturers said that it is very important to internalize AIK in the course, because it will be a differentiator/characteristic of a course taught at UMJ with other universities. It is important because students can relate the courses obtained with AIK scores Internalization of AIK in courses is one of the implementations of the institutional vision, namely Islamic. 
The form of Islam is how Islamic values can cover all fields in the tridharma of higher education. With this internalization, it is hoped that the vision of the Institution and Graduate Competence to produce graduates with noble character can be realized.

\section{The Existence of AIK Internalization in RPS and its Barriers}

Almost all courses do not include AIK Internalization in the RPS. There are only approximately 4 courses that have included course materials related to the Internalization of AIK.

Lecturers do not include AIK Internalization in the RPS, because of the limited knowledge of religion they have and find it difficult to put it in the RPS and there is no obligation to include it in the RPS. If social courses may be delivered, but if exact/technical courses are very difficult to link with AIK.

The internalization of AIK values in the RPS has not been carried out by all courses. This is because of the limited religious knowledge possessed by lecturers, to examine AIK values related to courses. Besides that, there is no lecturer's obligation to pour the Internalization. The absence of a policy regarding the obligation of lecturers to internalize has made lecturers not include AIK Internalization in the RPS.

The internalization of AIK is in the quality target of FT point 31 with a target of $75 \%$. The institution should conduct an audit of quality objectives so that it is known to what extent AIK's internalization is being carried out. The audit results are evaluated so that follow-up can be done.

\section{The Need for Internalization of AIK in RPS}

The internalization of AIK is necessary and important to be included in the RPS, so that it is easy for lecturers to convey to students so that whoever teaches can easily and the same material is delivered. If in the RPS courses, AIK values are included in each meeting or special material, then this can be a difference between RPS UMJ and other universities.

In the RPS courses, it is necessary to include Internalization of AIK, both in each material presented and the specific subject matter regarding the link between courses and AIK.

The inclusion of AIK values in the course is expected to make UMJ students and graduates able to become Muslim intellectuals who are obedient and devoted to Allah SWT.

Internalization of AIK in the courses as outlined in the RPS is the difference between RPS UMJ and other universities.

Care needs to be taken in entering the arguments or verses of the Qur'an and hadith, so that what is conveyed is truly pure truth.

Application proposal

All lecturers agree that if: a. AIK internalization is implemented, a policy or regulation is needed regarding this matter

b. Lecturers are given guidance, tutors, mentoring and detailed assessment of AIK values in subject matter, because lecturers feel minimal about religious knowledge and are less able to study verses of the Qur'an and Hadith

c. Guidance is given regarding the implementation of internalization in courses, socialized, monitoring is carried out in the implementation and evaluation.

The desire of all lecturers to internalize AIK in courses can be seen from the enthusiasm of lecturers who have internalized AIK on behavior. All lecturers feel the need for guidance, tutorials and assistance regarding the suitability of lecture material with verses from the Qur'an and hadith, because of the limitations of the lecturer's religious knowledge. The implementation of AIK Internalization in courses needs to be stated in the RPS so that lecturers can easily convey it to students so that whoever is in charge of the course will convey it the same.

There are 46 courses taught by 11 lecturers. Courses that have included Internalization. AIK in the courses listed in the Semester Learning Plan (RPS) are: Introduction to Economics, Engineering Economics, Industrial Psychology and Introduction to Business Management (4 courses). The percentage is $8.6 \%$. The Quality Goals set by the UMJ Faculty of Engineering, there has not been an audit regarding their performance.

Recommendations from the results of this study are:

a. Encouraging the leadership to issue policies sor rules regarding the obligation to carry out AIK Internalization in the courses listed in the RPS,

b. Making written guidelines and rules regarding technical implementation,

c. Conducting outreach to lecturers,

d. Provide Assistance and Guidance to Lecturers,

e. Carrying out Monitoring and Evaluation

\section{CONCLUSION}

a. Implementation of Internalization of AIK values in the currently implemented courses, only 4 courses that include AIK values or $8.6 \%$ of all courses.

b. The problems and obstacles experienced are the absence of obligations that require Internalization of AIK in courses, the limitations of Religious Studies and the limited time of lecturers.

c. The quality target for learning has not been achieved.

d. The recommendation is to encourage leaders to issue policies, technical guidelines, mentoring and monitoring.

\section{REFERENCE}

[1] B. Tamam, R. Al-Adawiyah, and A. Muadin, "Internalisasi NilaiNilai Pendidikan Agama Islam dalam Pembelajaran Pelajaran AlIslam dan Kemuhammadiyahan di SMA Muhammadiyah 1 
Sumenep Madura Jawa Timur," FENOMENA, vol. 9, no. 1, p. 67, 2017, doi: 10.21093/fj.v9i1.805.

[2] Faridi, "PERSEPSI MAHASISWA TERHADAP MATA KULIAH AL ISLAM DAN KEMUHAMMADIYAHAN (AIK) : INTERNALISASI NILAI-NILAI AIK BAGI MAHASISWA," Progres. J. Pemikir. dan Pendidik. Islam, vol. 4, no. 1, 2016, doi: 10.22219/progresiva.v4i1.1811.

[3] M. Munif, "STRATEGI INTERNALISASI NILAI-NILAI PAI DALAM MEMBENTUK KARAKTER SISWA," EDURELIGIA; J. Pendidik. AGAMA Islam, vol. 1, no. 2, pp. 1-12, 2017, doi: 10.33650/edureligia.v1i2.49.

[4] Z. Nuryana, "REVITALISASI PENDIDIKAN AL-ISLAM DAN KEMUHAMMADIYAHAN PADA PERGURUAN MUHAMMADIYAH." Center for Open Science, 2019, doi: 10.31219/osf.io/yk3qv.

[5] I. Alil, "Strategi Pemberdayaan Ekonomi Melalui Program Amal Usaha Muhammadiyah Pada Perdesaan Di Sumbawa BaratStrategi Pemberdayaan Ekonomi Melalui Program Amal Usaha Muhammadiyah Pada Perdesaan Di Sumbawa Barat," JPEK (Jurnal Pendidik. Ekon. dan Kewirausahaan), vol. 3, no. 2, pp. 92-100, 2019, doi: 10.29408/jpek.v3i2.1712.

[6] M. S. Khakim, "Deradikalisasi organisasi kemahasiswaan di perguruan tinggi Muhammadiyah Aisyiyah Daerah Istimewa Yogyakarta," J. Citizsh. Media Publ. Pendidik. Pancasila dan
Kewarganegaraan, vol. 1, no. 2, p. 84, 2018, doi: 10.12928/citizenship.v1i2.13621.

[7] H. Huda, "Membangun Karakter Islami Melalui Al Islam dan Kemuhammadiyahan [Studi Analisis Perpres Nomer 87 Tahun 2017 tentang Penguatan Pendidikan Karakter (PPK)]," TARLIM J. Pendidik. AGAMA Islam, vol. 2, no. 1, p. 55, 2019, doi: 10.32528/tarlim.v2i1.2071.

[8] A. Andriyani, A. Nata, and D. Saefuddin, "Implementasi Kurikulum Al-Islam dan Kemuhammadiyahan (AIK) Melalui Model Student Centered Learning (SCL) di Program Studi Pendidikan Dokter Fakultas Kedokteran dan Kesehatan Universitas Muhammadiyah Jakarta," Ta'dibuna J. Pendidik. Islam, vol. 3, no. 2, p. 141, 2016, doi: 10.32832/tadibuna.v3i2.591.

[9] M. Hazmi, D. W. Putra, A. Gunasti, and A. Jalil, "IDEOLOGI MUHAMMADIYAH." Universitas Muhammadiyah Jember, 2020, doi: 10.32528/342988839_ideologi.

[10] H. Nashir, "Purifikasi Islam dalam Gerakan Padri di Minangkabau," Unisia, vol. 31, no. 69, pp. 219-230, 2018, doi: 10.20885/unisia.vol31.iss69.art1.

[11] Mulyasa, Manajemen Berbasis Sekolah, Konsep, strategi dan Implementasi. Bandung: PT Remaja Rosdakarya. Bandung: PT Remaja Rosdakarya, 2017. 